\title{
HUBUNGAN ANTARA KEPERCAYAAN DIRI DENGAN AKTIVITAS BELAJAR SISWA
}

Oleh:

\author{
Moh. Kadir ${ }^{1)}$, Jahada ${ }^{2)}$ \\ 1) 2) Jurusan Bimbingan dan Konseling \\ Fakultas Keguruan dan Ilmu Pendidikan, Universitas Halu Oleo \\ Email: ${ }^{1)}$ mohkadir1993@gmail.com ${ }^{2)}$ jahadasahabudin77@gmail.com
}

\begin{abstract}
ABSTRAK
Tujuan penelitian ini adalah untuk mengetahui apakah hubungan antara kepercayaan diri dengan aktivitas belajar siswa SMA Negeri 1 Tongkuno. Penelitian ini merupakan penelitian korelasional. Populasi penelitian adalah 185 siswa dengan jumlah sampel 37 siswa. Pengambilan sampel dilakukan secara proposional random sampling. Data dikumpulkan dengan menggunakan skala kepercayaan diri dengan skala aktivitas belajar. Data diolah dengan menggunakan statistik deskriptif dan statistik inferensial. Berdasarkan hasil analisis yang telah ditemukan bahwa a) kepercayaan diri siswa berada di kategori sedang, b) aktivitas belajar siswa berada dikatgori tinggi dan c) ada hubungan yang signifikan antara kepercayaan diri dengan aktivitas belajar siswa SMA Negeri 1 Tongkuno. hal ini dapat dibuktikan dari nilai korelasi $\left(r_{x y}\right)=0,973\left(r_{\text {hitung }}=0,973>r_{\text {tabel }}=\right.$ 0,325) dan nilai koefisien Determinasi $\left(\mathrm{r}^{2}\right)$ 0,9467 yang berarti 94,67\%.
\end{abstract}

Kata Kunci: Kepercayaan Diri, Aktivitas Belajar

THE CORRELATION BETWEEN SELF CONFIDENT AND LEARNING ACTIVITIES

\begin{abstract}
The purpose of the research was to find out whether there is a correlation between the students self confidents and their learning activities. This was a correlational research. The population of the research was 185 students. Off the 185 students, only 37 students were taken as samples of the research. The samples were taken through random sampling. The data were collected through self confident scale and learning activities scale. The data were analyzed by using descriptive statistic and inferential statistic. The findings of the research reveal that a) the students self confidents are in low category, b) the students learning activities are in high category, and c) there is a significant correlation between the students self confidents and their learning activities of the high school students 1 Tongkuno. The evidence shows that its correlation value (rxy) is = 0.973 ( $($ rcount $=0.973>$ rtable $=0.325)$ with its coefficient determination $\left(r^{2}\right)$ is 0.9467 which it means that the final result is $94.67 \%$.
\end{abstract}

Keywords: Self-confidence, Learning Activities 


\section{Pendahuluan}

Aktivitas belajar dapat dilihat dari aktivitas fisik dan mental siswa selama proses pembelajaran. Jika siswa sudah terlibat secara fisik dan mental maka siswa akan merasakan suasana belajar yang lebih menyenangkan sehingga belajar dapat dimaksimalkan. Rasa percaya diri seseorang tidak muncul dan terbentuk begitu saja melainkan ada faktor-faktor memengaruhinya seperti lingkungan keluarga, pendidikan formal dan pendidikan non-formal. Kepercayaan diri seseorang bisa tumbuh dan berkembang dengan baik jika berada dalam lingkungan yang baik dan mendukung perkembangan rasa percaya diri seseorang seperti lingkungan yang mendukung untuk menumbuhkan sikap mandiri, perilaku bertanggung jawab, melatih keberanian berbicara dan berpendapat dan pemberian kebebasan terhadap anak untuk berekspresi dalam batas-batas yang telah ditentukan.

Aktivitas siswa dalam pembelajaran dapat merangsang dan mengembangkan bakat yang dimilikinya, berfikir kritis dan dapat memecahkan masalah-masalah dalam kehidupan sehari-hari. Aktivitas belajar ditandai dengan adanya siswa ikut berpartisipasi dalam proses pembelajaran dan pembelajaran tidak hanya berpusat pada guru semata melainkan dari pengalaman siswa sendiri saat mengikuti materi pelajaran di kelas. Di dalam belajar, kepercayaan diri sangat diperlukan, karena dengan adanya kepercayaan diri akan membuat siswa lebih berani dan aktif dalam belajar sehingga membuat aktivitas belajar menjadi baik.

Berdasarkan hasil wawancara yang dilakukan di SMA Negeri 1 Tongkuno pada tanggal 25 Oktober 2017 dengan Guru Mata Pelajaran dan Guru Bimbingan dan Konseling (BK) diketahui bahwa pelaksanaan pembelajaran menunjukkan setiap kali siswa yang mengikuti pelajaran apapun, biasanya guru akan memberikan kesempatan untuk bertanya kepada siswa yang belum memahami pelajaran yang baru saja diterangkan, tetapi yang terjadi adalah banyak siswa yang belum memahami pelajaran mereka, merasa malu, kurang memunyai keberanian untuk bertanya, masih ada siswa yang bercerita pada saat proses belajar, tidak memberikan tanggapan dalam pembelajaran, tidak berani memberikan kritikan, tidak memerhatikan penjalasan guru pada saat proses pembelajaran serta diam apabila diminta menjawab pertanyaan dari guru. Selain itu, mereka memiliki kepercayaan diri rendah sehingga mereka menunjukkan aktivitas belajar yang kurang aktif baik terhadap pelajaran maupun guru dalam proses pembelajaran.
Berdasarkan latar belakang tersebut, peneliti bermaksud melaksanakan penelitian dengan judul "Hubungan Antara Kepercayaan Diri dengan Aktivitas Belajar Siswa". Tujuan penelitian ini adalah untuk mengetahui apakah terdapat hubungan antara kepercayaan diri dengan aktivitas belajar siswa.

\section{Aktivitas belajar}

Hamalik (2009: 179) menjelaskan bahwa aktivitas belajar merupakan kegiatan yang dilakukan siswa dalam kegiatan pembelajaran. Ketika siswa belajar dengan aktif, berarti siswa yang mendominasi aktivitas belajar. Dengan ini mereka secara aktif menggunakan otak, baik untuk menemukan ide pokok dari materi, memecahkan persoalan atau mengaplikasikan apa yang baru mereka pelajari ke dalam persoalan yang ada dalam kehidupan nyata.

Belajar sangat dibutuhkan adanya aktivitas, dikarenakan tanpa adanya aktivitas, proses belajar tidak mungkin berlangsung dengan baik. Pada proses aktivitas pembelajaran harus melibatkan seluruh aspek peserta didik, baik jasmani maupun rohani sehingga perubahan perilakunya dapat berubah dengan cepat, tepat, mudah dan benar, baik berkaitan dengan aspek kognitif afektif maupun psikomotor (Hanafiah, 2010: 23).

Dalam belajar diperlukan adanya aktivitas, sebab pada prinsipnya belajar adalah berbuat untuk mengubah tingkah laku atau melakukan sesuatu aktivitas. Tidak ada belajar kalau tidak ada aktivitas sehingga suatu pembelajaran akan lebih efektif jika dalam pembelajaran tersebut mnyediakan kesempatan pada siswa untuk belajar sendiri atau melakukan aktivitas sendiri. Dengan demikian dalam pelaksanaan kegiatan pembelajaran sangat diperlukan adanya aktivitas siswa agar materi yang diberikan akan lebih lama tersimpan di dalam benak siswa. Aktivitas belajar siswa tidak hanya mendengar atau mencatat saja. Banyak jenis aktivitas yang dapat dilakukan oleh siswa di sekolah.

Dari uraian tersebut, dapat disimpulkan bahwa aktivitas belajar merupakan kegiatan yang dilakukan siswa dalam mengikuti pembelajaran yang dilakukan guna mendapatkan perubahan kearah yang lebih baik. Aktivitas belajar suatu perubahan tingkah laku dalam diri seseorang berupa pengetahuan, pemahaman maupun sikap yang diperoleh melalui proses belajar, jika siswa melakukan aktivitas belajar maka kegiatan mengajar akan berjalan efektif. Proses pembelajaran dikatakan efektif bila peserta didik secara aktif ikut terlibat langsung dalam 
pengorganisasian dan penemuan informasi (pengetahuan) sehingga mereka tidak hanya menerima secara pasif pengetahuan yang diberikan oleh guru. Dalam proses belajar mengajar tugas guru adalah mengembangkan dan menyediakan kondisi agar peserta didik dapat mengembangkan bakat dan potensinya.

\section{Jenis-jenis Aktivitas Belajar}

Rusman (2017: 90-93) menyatakan aktivitas belajar ada beberapa jenis, di antaranya: 1) Belajar arti kata, 2) Belajar kognitif, 3) Belajar menghafal, 4) Belajar teoritis, 5) Belajar konsep, 6) Belajar kaidah, 7) Belajar berpikir, 8) Belajar keterampilan motoric dan 9) Belajar estetis.

Pendapat berbeda diuraikan oleh Diedrich

(dalam Hanafiah dan Sunaha 2010: 24) menyatakan aktivitas belajar di bagi 8 (delapan) kelompok yaitu sebagai berikut: 1) Kegiatankegiatan visual (visual activities), 2) Kegiatankegiatan lisan (oral activities), 3) Kegiatankegiatan mendengarkan (listening activities), 4) Kegiatan-kegiatan menulis (writing activities), 5) Kegiatan-kegiatan menggambar (drawing activities), 6) Kegiatan-kegiatan motorik (motor activities), 7) Kegiatan-kegiatan mental (mental activities) dan 8) Kegiatan-kegiatan emosional (emotional activities).

\section{Kepercayaan Diri}

Fatimah (2015:96) menyatakan bahwa kepercayaan diri merupakan keyakinan seseorang terhadap segala aspek kelebihan yang dimilikinya dan keyakinan tersebut membuatnya merasa mampu untuk bisa mencapai berbagai tujuan di dalam hidupnya. Individu yang percaya diri akan merasa yakin terhadap dirinya sendiri. Individu juga merasa optimis dalam melakukan segala aktivitasnya sehingga dapat mengoptimalkan kelebihan-kelebihannya serta dapat membuat tujuan hidup yang realistik bagi dirinya. Artinya, individu itu menetapkan tujuan hidup yang tidak terlalu tinggi baginya sehingga ia dapat mencapai tujuan hidup yang ia tentukan. Individu yang dapat mencapai tujuan hidupnya akan merasa mampu untuk melakukan sesuatu dalam dirinya sendiri.

Kepercayaan diri dapat dikatakan sebagai unsur kepribadian yang merupakan perasaan individual seseorang berupa kesadaran dan keyakinan atas kemampuan diri untuk merealisasikan harapan. Kepercayaan diri merupakan salah satu aspek kepribadian individu yang berfungsi mendorong individu dalam meraih kesuksesan melalui hasil interaksi antara individu dengan lingkungannya untuk berperilaku sesuai dengan yang diharapkan, bekerja secara efektif serta dapat melaksanakan tugas dengan baik dan tanggung jawab.

\section{Aspek-aspek Kepercayaan Diri}

Ghufron \& Risnawita (2011: 35) menjelaskan bahwa seseorang yang memunyai kepecayaan diri tinggi akan mampu bergaul secara fleksibel, memunyai toleransi yang cukup baik, bersikap positif, tidak mudah terpengaruh orang lain dalam bertindak dan mampu menentukan langkah-langkah pasti dalam kehidupannya. Lauster dalam (Ghufron \& Risnawita, 2011: 35) juga menyatakan bahwa orang yang memunyai kepercayaan diri yang positif adalah orang yang memiliki: 1) Keyakinan kemampuan diri, 2) Optimis, 3) Obejktif, 4) Bertanggung jawab, 4) Rasional.

\section{Proses Terbentukya Kepercayaan Diri}

Proses terbentuknya rasa percaya diri merupakan sebuab proses psikologis. Dalam perjalanan hidupnya manusia harus mengalami proses belajar. Sikap dan perasaan seseorang juga mengalami perkembangan sejalan dengan proses belajar yang dialami. Demikian juga halnya dengan rasa percayaan diri pada seseorang bukanlah suatu sifat turunan yang langsung dimiliki tanpa adanya proses belajar.

Hakim (2005: 61) menjelaskan bahwa secara garis besar terbentuknya kepercayaan diri yang kuat terjadi melalui proses sebagai berikut: 1) Terbentuknya kepribadian yang baik sesuai proses perkembangan yang melahirkan kelebihankelebihan tertentu, 2) Pemahaman seseorang terhadap kelebihan-kelebihan yang dimilikinya dan melahirkan keyakinan kuat untuk bisa berbuat segala sesuatu dengan memanfaatkan kelebihankelebihannya, 3) Pemahaman dan reaksi positif seseorang terhadap kelemahan-kelemahan yang dimilikinya agar tidak menimbulkan rasa rendah diri atau sulit menyesuaikan diri, 4) Pengalaman di dalam menjalani aspek kehidupan dengan menggunakan segala kelebihan yang ada pada dirinya.

Terbentuknya percaya diri diawali dengan terbentuknya kepribadian yang baik sesuai perkembangannya, pemahaman diri terhadap kelebihan dan kelemahan, reaksi positif terhadap kelemahan serta adanya pengalaman menggunakan kelebihannya sehingga rasa percaya diri dapat terbentuk.

\section{Ciri-ciri Kepercayaan Diri}


Lauster (dalam Wahyuni 2014: 149) mengemukakan tentang ciri-ciri kepercayaan diri yaitu: 1) percaya kepada kemampuan sendiri, 2) bertindak mandiri dalam mengambil keputusan, 3) Memiliki rasa positif terhadap diri dan 4) Berani mengungkapkan pendapat. Selanjutnya, pendapat Lina dan Klara (2010: 16) menyebut beberapa ciri atau karakteristik individu yang memunyai rasa percaya diri terbagi 2 yaitu:

1. Percaya diri yang proposional yakni:

a. Percaya atas kompetensi/ kemampuan diri,

b. Tidak terdorong untuk menunjukkan sikap yang menyesuaikan diri demi diterima oleh orang lain atau kelompok,

c. Berani menerima dan menghadapi penolakan orang lain,

d. Memiliki harapan yang realitis terhadap diri sendiri.

2. Kurang percaya diri yaitu sebagai berikut:

a. Berusaha menunjukkan sikap konformis,

b. Menyimpan rasa takut/ kekhawatiran terhadap penolakan,

c. Sulit menerima realita diri (terlebih menerima kekurangan diri) dan memandang rendah kemampuan diri sendiri,

d. Pesimis, mudah menilai segala sesuatu dari bsisi negatif,

e. Takut gagal,

f. Cenderung menolak pujian yang ditunjukansecara tulus,

g. Selalu menempatkan/ memosisikan diri sebagai yang terakhir karena menilai dirinya tidak mampu,

h. Memunyai external locus of control.

Fatimah (2015: 96) mengemukakan bahwa kepercayaan diri adalah suatu keyakinan seseorang terhadap segala aspek kelebihan yang dimilikinya dan keyakinan tersebut membuatnya merasa mampu untuk mencapai tujuan dalam hidupnya. Kepercayaan diri merupakan keyakinan akan kemampuan yang dimiliki untuk berfikir, bertindak secara aktif dan mandiri untuk mencapai suatu tujuan yang diharapkan. Siswa-siswa yang memiliki kepercayaan diri akan berusaha semaksimal mungkin untuk mencapai prestasi sesuai dengan kemampuan yang dimilikinya. Bekal dari kepercayaan diri banyak hal yang bisa dilakukan oleh siswa, siswa akan mampu menangani segala sesuatu dengan tenang. Secara sederhana, kepercayaan diri dikatakan sebagai untuk keyakinan seorang terhadap segala aspek yang dimilikinya dan keyakinan tersebut membuat merasa mampu untuk mencapai tujuan-tujuan di dalam hidupnya.
Aktivitas belajar, pada dasarnya belajar memerlukan aktivitas, aktivitas tersebut yang terlihat dalam proses belajar mengajar. Hamalik (2009: 179) menjelaskan bahwa aktivitas belajar merupakan kegiatan yang dilakukan oleh siswa dalam kegiatan pembelajaran. Ketika siswa belajar dengan aktif, berarti siswa yang mendominasi aktivitas pembelajaran. Dengan ini mereka secara aktif menggunakan otak, baik untuk menemukan ide pokok dari materi, memecahkan persoalan atau mengaplikasikan apa yang baru mereka pelajari ke dalam persoalan yang ada dalam kehidupan nyata.

Dapat disimpulkan dalam melakukan aktivitas belajar sangat diperlukan kepercayaan diri, karena dengan adanya sikap tersebut akan membuat siswa lebih berani dan siswa lebih aktif dalam melakukan aktivitas belajar sehingga terciptanya aktivitas belajar yang lebih baik. Siswa yang memunyai kepercayaan diri yang tinggi akan terlihat lebih tenang, tidak memiliki rasa takut dan mampu memperlihatkan kepercayaan dirinya setiap saat dalam belajar dan begitu juga dengan aktivitas belajar, semakin baik aktivitas belajar siswa maka tercapailah tujuan pengajaran yang dilakukan oleh guru, karena tercapainya tujuan pengajaran sangat dipengaruhi bagaimana aktivitas siswa di dalam belajar.

Hubungan kepercayaan diri dan aktivitas belajar memunyai yang erat, tanpa adanya kepercayaan diri, seorang siswa tidak akan bisa melakukan aktivitas belajar dengan maksimal dalam proses pembelajaran. Sebagai siswa harus memperlihatkan kepercayaan diri pada saat menyelesaikan tugas dengan sendiri tanpa bantuan orang lain, dapat menyelesaikan tugas tepat waktu dan dapat mengatasi masalah yang dihadapinya. Tingkat kepercayaan diri seseorang menentukan keberhasilan seseorang. Karena dengan adanya kepercayaan diri siswa akan lebih aktif, berani dalam belajar sehingga menciptakan aktivitas belajar yang baik.

Kepercayaan diri merupakan salah satu aspek yang sangat diperlukan oleh individu untuk dapat tumbuh dan berkembang dengan baik. Siswa Sekolah Menengah Atas (SMA) perlu untuk mengembangkan kepercayaan diri yang baik agar mampu untuk menghadapi berbagai masalah dan tugas-tugas perkembangan yang akan dihadapinya, baik di sekolah maupun di luar sekolah. Peserta didik yang memiliki kepercayaan diri yang rendah akan cenderung tidak memiliki konsep diri yang kuat. Sementara peserta didik perlu mengembangkan kepercayaan diri yang baik agar dapat menyesuaikan diri terhadap berbagai keadaan yang ada di lingkungan serta 
menyelesaikan diri terhadap berbagai keadaan yang ada di lingkungan serta menyelesaikan berbagai konflik sebagai proses mencari identitas diri.

Aktivitas belajar tersebut sangat efektif untuk mengembangkan atau meningkatkan aktivitas belajar dan kepercayaan diri siswa. Belajar adalah suatu proses perubahan tingkah laku dalam diri individu yang dilakukan dengan suatu usaha-usaha untuk memperoleh pengalaman dalam hidupnya yang berlangsung secara terus-menerus. Saat proses aktivitas belajar, banyak faktor yang memengaruhi keberhasilan belajar siswa.

Siswa yang memiliki kepercayaan diri yang tinggi akan menampilkan aktivitas belajar yang baik dalam hal ini siswa akan menunjukkan sikap positif dalam menerima pelajaran, siswa akan merasakan kenyamanan serta menunjukkan keseriusan dalam belajar. Selain itu juga dengan kepercayaan diri yang dimiliki, siswa yang akan lebih mudah dalam mengemukakan ide-ide kreatif, tenang serta tidak ragu-ragu dalam mengemukakan pendapat, memerhatikan penjelasan guru pada saat pebelajaran dan menjawab pertanyaan yang dberikan oleh guru.

\section{Metode Penelitian}

Penelitian ini dilaksanakan di SMA Negeri 1

Tongkuno, Desa Lahontohe, Kecamatan Tongkuno, Kabupaten Muna. Penelitian akan dilaksanakan selama tujuh bulan yakni dimulai sejak Bulan Oktober 2017 sampai bulan Mei tahun 2018.

Jenis penelitian ini adalah penelitian kuantitatif dengan pendekatan korelasional, yakni suatu penelitian yang bertujuan untuk memberikan gambaran hubungan antara satu variabel dengan variabel yang lain, dimana dimaksudkan untuk mengetahui hubungan antara kepercayaan diri dengan aktivitas belajar siswa SMA Negeri 1 Tongkuno. Desain yang digunakan dalam penelitian ini, yaitu variabel kepercayaan diri sebagai variabel bebas simbol $\mathrm{X}$ dan aktivitas belajar variabel terikat disimbol Y.

Populasi dalam penelitian ini adalah seluruh siswa SMA Negeri 1 Tongkuno yang berjumlah 185 orang. Pengambilan sampel menggunakan metode simple random sampling sebanyak $20 \%$ dari total jumlah populasi atau sebanyak 37 orang siswa.

Penelitian ini menggunakan alat pengumpul data berupa angket. Angket yang akan digunakan terlebih dahulu diuji coba, untuk memenuhi kriteria yang telah ditetapkan dalam penelitian ilmiah yaitu validitas dan reabilitas. Uji validitas dan uji reliabilitas pada instrumen menggunakan bantuan program komputer Statistical Packages for Social Science (SPSS) versi 16.0. Adapun kriteria yang digunakan untuk uji validitas adalah apabila nilai $r_{x y}>r_{\text {tabel }}$ dengan taraf signifikan sebesar $0,05 \%$ maka instrumen dikatakan valid. Uji reliabilitas ini didasarkan pada ketentuan bahwa apabila nilai $r_{\text {hitung }}>r_{\text {tabel }}$ maka instrumen dikatakan reliabel.

Teknik analisis data menggunakan analisis statistik deskriptif untuk mengetahui gambaran kepercayaan diri dan aktivitas belajar siswa dan statistik inferensial digunakan untuk menguji hipotesis penelitian menggunakan analisis korelasi product moment dengan menggunakan bantuan aplikasi SPSS Version 16.0.

\section{Hasil Penelitian dan Pembahasan Hasil Penelitian}

Analisis Deskriptif Kepercayaan Diri

Data kepercayaan diri siswa diukur dengan menggunakan angket yang terdiri dari 37 pernyataan dengan menggunakan skala 1 sampai 4 . Sehingga skor tertinggi jawaban setiap pertanyaan adalah 4 dan skor terendah 1 . Adapun hasil analisis deskriptif skor kepercayaan diri menggunakan aplikasi SPSS Version 16.0 diperoleh data hasil kepercayaan diri yang disajikan sebagai berikut:

Tabel 1

Analisis Deskriptif Variabel Kepercayaan Diri

\begin{tabular}{|c|c|c|c|c|c|c|}
\hline \multicolumn{6}{|c|}{ Descriptive Statistics } \\
\hline & N & Min & Max & Mean & $\begin{array}{c}\text { Std. } \\
\text { Deviation }\end{array}$ & Variance \\
\hline $\mathrm{X}$ & 37 & 92 & 135 & 115.51 & 10.966 & 120.257 \\
\hline Valid N & 37 & & & & & \\
\hline
\end{tabular}

Data hasil analisis deskriptif variabel kepercayaan diri menggunakan aplikasi SPSS Version 16.0 menunjukkan bahwa dari 37 yang mengisi angket maka skor kepercayaan diri adalah berdistribusi skor minimum 92, skor maximum 135, rata-rata (mean) 115,51, simpangan baku (standar deviation) 10,966, variance 120,257.

\section{Analisis Deskriptif Aktivitas Belajar}

Data aktivitas belajar siswa diukur dengan menggunakan angket yang terdiri dari 42 pernyataan dengan menggunakan skala 1 sampai 4 . Adapun hasil analisis deskriptif skor aktivitas belajar menggunakan aplikasi SPSS Version 16.0 diperoleh data aktivitas belajar yang disajikan pada tabel 2 sebagai berikut:

Tabel 2

Analisis Deskriptif Variabel Aktivitas Belajar 


\begin{tabular}{|c|c|c|c|c|c|c|}
\hline \multicolumn{6}{|c|}{ Descriptive Statistics } \\
\hline & $\mathrm{N}$ & Min & Max & Mean & $\begin{array}{c}\text { Std. } \\
\text { Deviation }\end{array}$ & Variance \\
\hline Y & 37 & 99 & 162 & 139.03 & 14.288 & 204.138 \\
\hline Valid N & 37 & & & & & \\
\hline
\end{tabular}

Berdasarkan data hasil analisis deskriptif variabel aktivitas belajar siswa Dengan menggunakan aplikasi SPSS Version 16.0 diterangkan bahwa terdapat 37 orang siswa yang mengisi angket dengan skor minimum 99, skor maksimum 162, rata-rata (mean) 139.03, simpangan baku (standar deviation) 14.288, variance 204.138.

\section{Analisis Statistik Inferensial}

Pengujian hipotesis penelitian menggunakan analisis korelasi product moment dengan menggunakan bantuan aplikasi SPSS Version 16.0. Hasil uji hipoteis menunjukkan bahwa nilai koefisien korelasi data nilai angket kepercayaan diri dan aktivitas belajar sebesar 0,973. Dengan demikian nilai $r_{\text {hitung }}=0,973>r_{\text {tabel }}=0,325$, yang berarti bahwa terdapat hubungan yang sangat kuat antara kepercayaan diri (X) dengan aktivitas belajar siswa (Y). Oleh karena itu, maka hipotesis penelitian $\left(\mathrm{H}_{\mathrm{a}}\right)$ yang menyatakan bahwa ada hubungan yang siginifikan antara kepercayaan diri dengan aktivitas belajar siswa kelas XI SMA Negeri 1 Tongkuno diterima.

Uji signifikansi antara variabel kepercayaan diri dengan aktivitas belajar di peroleh nilai $t_{\text {hitung }}=$ 25,027 jika dibandingkan dengan $t_{\text {tabel }}$ pada $\alpha=$ $0,05 \mathrm{db}=\mathrm{n}-2=37-2=35$ (yang mendekati 37) sehingga diperoleh $t_{\text {tabel }}=2,030$ yang berarti ada hubungan positif yang sigifikan antara kepercayaan diri dengan aktivitas belajar siswa kelas XI SMA Negeri 1 Tongkuno.

\section{Pembahasan}

Berdasarkan studi pendahuluan pada siswa SMA Negeri 1 Tongkuno ditemukan indikasi bahwa siswa memiliki masalah pada aktivitas belajar. Informasi yang diperoleh adalah bahwa siswa merasa malu, kurang memunyai keberanian untuk bertanya, tidak memberikan tanggapan, masih ada siswa yang bercerita pada saat proses belajar serta tidak memerhatikan penjelasan guru pada saat proses pembelajaran. Hal ini bisa terjadi karena siswa kurang memaknai apa yang sedang menjadi bahan belajarnya. Siswa merasa dirinya tidak yakin dengan akan kemampuan dirinya atas pelajaran yang diikuti, siswa merasa tidak memerlukan pelajaran tersebut serta siswa juga mengikuti temannya yang sedang bermain. Dengan kata lain, siswa menunjukkan adanya kepercayaan diri yang rendah dalam aktivitas belajarnya. Hal ini menimbulkan keinginan peneliti untuk meneliti apakah ada hubungan antara kepercayaan diri dengan aktivitas belajar siswa SMA Negeri 1 Tongkuno.

Temuan pada penelitian mengungkapkan bahwa ternyata terdapat hubungan antara kepercayaan diri dengan aktivitas belajar siswa SMA Negeri 1 Tongkuno. Hubungan antara kepercayaan diri dengan aktivitas belajar siswa kelas XI SMA Negeri 1 Tongkuno tersebut ditandai dengan besaran koefisien korelasi sebesar 0,973 atau bersifat sangat tinggi. Hal ini mengambarkan bahwa kepercayaan diri merupakan salah satu faktor pendukung terjadinya aktivitas belajar siswa.

Siswa dengan kepercayaan diri yang tinggi akan bisa menempatkan dirinya dengan baik. Ia juga akan mampu beraktivitas dengan baik. Dalam aktivitas belajar hendaklah siswa meningkatkan kepercayaan dirinya. Hal ini sejalan dengan teori yang dikemukakan Fatimah (2015: 96) bahwa kepercayaan diri adalah suatu keyakinan seseorang terhadap segala aspek kelebihan yang dimilikinya dan keyakinan tersebut membuatnya merasa mampu untuk mencapai tujuan dalam hidupnya. Dengan demikian, dapat dikatakan bahwa, apabila seseorang ingin memiliki keyakinan dalam aktivitas belajar, maka ia harus mampu mengembangkan kepercayaan dirinya.

Hasil temuan dalam penelitian ini mendukung pendapat yang dikemukakan Ghufron \& Risnawita (2011: 35) bahwa seseorang yang memunyai kepercayaan diri tinggi akan mampu bergaul secara fleksibel, memunyai toleransi yang cukup baik, bersikap positif, tidak mudah terpengaruh orang lain dalam bertindak dan mampu menentukan langkah-langkah pasti dalam kehidupannya. Orang yang memunyai kepecayaan diri tinggi akan mampu bergaul secara fleksibel, memunyai toleransi yang cukup baik, bersikap positif, tidak mudah terpengaruh orang lain dalam bertindak dan mampu menentukan langkahlangkah pasti dalam kehidupannya.

Merujuk pada hasil yang diperoleh dalam penelitian ini, diharapkan Guru Mata Pelajaran dan Guru Bimbingan dan Konseling (BK) meningkatkan kepercayaan diri siswa selama menempuh pendidikan di sekolah serta dapat meminimalisir efek negatif yang timbul pada siswa yang memiliki kepercayaan diri yang rendah.

\section{Kesimpulan dan Saran Kesimpulan}


Berdasarkan analisis dan pembahasan hasil penelitian dalam penelitian dapat disimpulkan bahwa terdapat hubungan yang signifikan antara kepercayaan diri dengan aktivitas belajar siswa SMA Negeri 1 Tongkuno, hal ini dapat dibuktikan dari nilai korelasi $\left(\mathrm{r}_{\mathrm{xy}}\right)=0,973\left(\mathrm{r}_{\text {hitung }}=0,973>\mathrm{r}_{\text {tabel }}\right.$ $=0,325)$ dan nilai koefisien Determinasi $\left(r^{2}\right)$ 0,9467 yang berarti $94,67 \%$.

\section{Saran}

Berdasarkan hasil pembahasan dan kesimpulan dalam penelitian ini maka penulis memberikan saran sebagai berikut:

1. Bagi guru mata pelajaran agar bekerja sama dengan guru BK (Bimbingan dan Konseling) dalam meningkatkan aktivitas belajar siswa terutama memberikan masukan agar siswa terampil dalam belajarnya baik sesama teman maupun guru.

2. Kepada pihak sekolah agar senantiasa berupaya memberikan program-program bimbingan dan konseling yang diselenggarakan oleh guru $\mathrm{Bk}$. Kepada pihak sekolah memberikan layananlayanan bimbingan dan konseling sehingga dapat meningkatkan aktivitas belajar siswa agar mencapai prestasi yang lebih baik demi terwujudnya tujuan pendidikan yang diharapkan.

3. Bagi siswa harus memiliki aktivitas belajar karena dengan adanya aktivitas belajar yang baik maka siswa unggul dalam aspek akademis saja namun unggul dalam aspek kepribadian dari keunggulan yang siswa miliki maka akan lebih menonjol atau semakin nampak kepercayaan diri mereka karena didasari dengan berbagai yang mereka miliki. Semakin baik aktivitas belajar mereka akan semakin tinggi kepercayaan diri mereka.

\section{Daftar Pustaka}

Fatimah, Dewi. (2015). Pengembangkan Bimbingan Kelompok Dengan Teknik Rore Playing Untuk Mengembangkan Kepercayaan Diri Siswa SMP 40 Semarang. Jurnal. Bimbingan Dan Konseling. Volume 4. No 1.

Ghufron, M Nur dan Risnawati S Rini. (2011). Teori-Teori Psikologi. Yogyakarta: Ar-Ruz Media.

Hakim, Thursan. (2005). Mengatasi Rasa Tidak Percaya Diri. Jakarta: Puswa Swara.
Hamalik, Oemar. (2009). Proses Belajar Mengajar. Bandung: Bumi Aksara.

Hanafiah, Nanang \& Cucu Suhana. (2010). Konsep Strategi Pembelajaran. Bandung: Refika Aditama.

Lina dan Sr. Klara. (2010). Panduan Menjadi Remaja Percaya Diri. Jakarta Timur: Nobel Edumedia.

Rusman. (2017). Belajar dan Pembelajaran, Beroreientasi Standar Proses Pendidikan. Jakarta: Kencana.

Wahyuni, Sri. (2014). Hubungan Antara Kepercayaan Diri Dengan Kecemasan Berbicara Di Depan Umum Pada Mahasiswa Psikolog. Journal Psikologi.Vol. 2. No.1, Hal 50-64. 
